\title{
KESIAPSIAGAAN BENCANA ERUPSI GUNUNG BARU JARI PADA MASYARAKAT DI KECAMATAN SEMBALUN KABUPATEN LOMBOK TIMUR
}

\author{
Nurhalimah, I Gd Astra Wesnawa, Ida Bagus Made Astawa \\ Program Studi Pendidikan Geografi \\ Universitas Pendidikan Ganesha \\ Singaraja, Indonesia
} e-mail: $\frac{\{\text { nurhalimah ok@yahoo.com }}{\text { idabagusmadeastawa@yahoo.com\}@undiksha.ac.id }}$

\begin{abstract}
Abstrak
Penelitian ini dilaksanakan di Kecamatan Sembalun, Kabupaten Lombok Timur dengan tujuan: (1) menganalisis tingkat kesiapsiagaan bencana erupsi Gunung Api Baru Jari pada masyarakat Sembalun di Kabupaten Lombok Timur, (2). Menganalisis faktor-faktor yang mempengaruhi tingkat kesiapsiagaan bencana erupsi Gunung Api Baru Jari pada masyarakat Sembalun di Kabupaten Lombok Timur, dan (3) Menganalisis kendala yang dihadapi masyarakat dalam meningkatkan kesiapsiagaan terhadap bencana erupsi Gunung Api di Kecamatan Sembalun Kabupaten Lombok Timur. Rancangan penelitian yang digunakan adalah rancangan penelitian deskriptif. Sampel diambil dengan teknik Proporsional Random Sampling. Pengumpulan data primer menggunakan metode koesioner dan data sekunder menggunakan pencatatan dokumen, yang selanjutnya dianalisis dengan metode deskriptif kualitatif.

Hasil penelitian menunjukkan bahwa (1) Tingkat kesiapsiagaan bencana erupsi Gunung Baru Jari pada masyarakat di Kecamatan Sembalun terkategori tidak siap dengan capaian skor rata-rata 27,53, (2) Faktor yang paling mempengaruhi tingkat kesiapsiagaan bencana erupsi Gunung Baru Jari di Kecamatan Sembalun adalah faktor sistem informasi sebanyak $57,41 \%$, dan (3) Kendala yang paling dominan yang dihadapi masyarakat dalam meningkatkan kesiapsiagaan bencana erupsi yaitu kendala ketersediaan sarana transportasi sebanyak $51,61 \%$.
\end{abstract}

Kata kunci: Tingkat Kesiapsiagaan, Faktor yang mempengaruhi, Kendala, Bencana Erupsi. 


\title{
KESIAPSIAGAAN BENCANA ERUPSI GUNUNG BARU JARI PADA MASYARAKAT DI KECAMATAN SEMBALUN KABUPATEN LOMBOK TIMUR
}

\author{
Nurhalimah, I Gd Astra Wesnawa, Ida Bagus Made Astawa \\ Geography Education Department \\ Ganesha University of Education \\ Singaraja, Indonesia \\ e-mail: $\frac{\{\text { nurhalimah ok@yahoo.com, gede astrawesnawa@yahoo.co.id, }}{\text { idabagusmadeastawa@yahoo.com\}@undiksha.ac.id }}$
}

\begin{abstract}
This research was conducted in the Sembalun District, East Lombok. This research the purpose of: (1) analyze the level of preparedness of the eruption of Volcano Baru Jari on society Sembalun East Lombok, (2). Analyzes the factors that influence the level of preparedness of the eruption of Volcano Baru Jari on society Sembalun East Lombok, and (3) to analyze the obstacles people face in improving disaster preparedness volcano eruption in the district Sembalun, East Lombok. The design study is a descriptive research design. Samples were taken using Rendom Proportional Sampling. The primary data collection using questioner and secondary data using a recording of the document, which is then analyzed by qualitative descriptive method.

The results showed that (1) The level of preparedness of the eruption of volcano Baru Jari on the people in the District Sembalun clasificate not ready with an average performance score of $27.53,(2)$ Factors that most influence the level of disaster preparedness of eruption of volcano Baru Jari in Sembalun District is information system factor as much as $57,41 \%$, and (3) The most dominant obstacle faced by society in increasing disaster preparedness erupsi namely constraint of transportation facility availability 51 , $61 \%$.
\end{abstract}

Keywords: Level of Preparedness, influencing factors, constraints, disaster eruption. 


\section{PENDAHULUAN}

Indonesia merupakan negara yang rawan terhadap bencana. Hal tersebut di sebabkan Indonesia dilewati oleh dua jalur pegunungan muda dunia, yakni pegunungan muda Sirkum Pasifik dan pegunungan muda Sirkum Mediterania. Selain itu, gugusan pulau Indonesia dalam tatanan tektonik dunia merupakan wilayah pertemuan tiga lempeng besar, yaitu Lempeng Eurasia (bagian barat laut), Lempeng Samudera HindiaAustralia (bagian selatan), dan Lempeng Samudera Pasifik (bagian timur laut) yang saling bergerak (Kardinasari, 2014).

Kondisi geologis Indonesia yang demikian, berdampak besar terhadap kehidupan bangsa indonesia sendiri. Pada satu sisi kondisi tersebut berdampak positif, yaitu tingginya sumber daya geologi yang dimiliki Indonesia, seperti banyaknya tersebar cebakancebakan minyak, gas bumi, batu bara, mineral, logam, mineral logam, air tanah, dan lain sebgainya. Namun pada sisi lain, kondisi tersebut berdampak negatif, yaitu tingginya ancaman bahaya geologi di Indonesia. Hampir seluruh wilayah Indonesia berpotensi rawan terhadap bencana, salah satunya adalah bencana erupsi gunung api.

Berdasarkan data Badan Nasional Penanggulangan Bencana (BNPB) pada periode tahun 2000 hingga tahun 2012, bencana erupsi gunung api merupakan bencana yang paling sering terjadi di Indonesia. Terdapat 80 kejadian erupsi gunung api dengan korban jiwa sebanyak 792 orang dan mengakibatkan sebanyak 238.758 orang terpaksa mengungsi. Kemudian pada akhir tahun 2016 bencana erupsi gunung api kembali terjadi di salah satu wilayah Indonesia, yakni erupsi Gunung Baru Jari di Lombok Timur tepatnya di Kecamatan Sembalun, Kabupaten Lombok Timur. Erupsi Gunung api kali ini tidak ada korban jiwa, namun demikian hal tersebut harus tetap diwaspadai mengingat pada erupsi sebelumnya, yakni pada tahun 2009 erupsi Gunung Baru Jari menimbulkan korban jiwa sebanyak 31 orang (BNPB 2009:16).

Gunung Baru Jari merupakan sumber kerawanan bencana bagi masyarakat di wilayah Kecamatan Sembalun Kabupaten Lombok Timur. Gunung ini sudah tercatat 3 kali erupsi selama pemunculannya (BMKG, 2016). Gunung Baru Jari ini disebut sebagai anak dari Gunung Rinjani oleh masyarakat Lombok yang memiliki ketinggian 2.2963.726 mdpl. Daerah yang paling dekat dengan Gunung Baru Jari adalah daerah Sembalun Timba Gading yang berjarak sekitar $13 \mathrm{~km}$ (BPS Kabupaten Lombok Timur, 2016).

Secara geografis Jumlah penduduk di Kecamatan Sembalun pada tahun 2015 mencapai 19.743 jiwa, yang terdiri dari 6 Desa yaitu Desa Sembalun Bumbung, Desa Sembalun Lawang, Desa Sajang, Desa Bilok Petung, Desa Sembalun dan Desa Sembalun Timba Gading. Kepadatan penduduk tertinggi terdapat di Desa Sajang yaitu $168,38 \mathrm{jiwa} / \mathrm{km}^{2}$ dan kepadatan penduduk terendah berada di Desa Sembalun Timba Gading yaitu sebesar 44,89 jiwa/km² (Kecamatan Sembalun dalam angka 2016). Penduduk di Kecamatan Sembalun sebagian besar bermata pencaharian di sektor pertanian, baik sebagai petani yang mempunyai lahan atau sebagai buruh tani. Data tersebut menunjukkan adanya penggunaan areal pertanian yang berhadapan langsung dengan Gunung Baru Jari. Hal inilah yang menyebabkan penduduk di kecamatan Sembalun akan terkena 
langsung dampak dari aktivitas gunung yang masih tergol ong aktif. Keberadaan Gunung Baru Jari bagi masyarakat Sembalun memiliki posisi di kotomi yakni di satu sisi sebagai sumber bencana, namun di sisi lain merupakan anugerah bagi masyarakat Sembalun sendiri yang tinggal di sekitar lereng gunung. Tingginya daya dukung lahan dan cadangan air tanah yang melimpah inilah yang menjadi daya tarik bagi masyarakat Sembalun untuk bertempat tinggal, sehingga mendorong tumbuhnya permukiman di kawasan tersebut. Namun demikian karena kondisi Gunung Baru Jari yang tergolong masih aktif, tidak menutup kemungkinan masyarakat Sembalun akan terkena oleh bencana erupsi gunung Baru Jari pada periode berikutnya.

Letusan gunung api merupakan salah satu bencana yang ditakuti oleh manusia, karena dampak yang ditimbulkan bisa menimbulkan kerusakan yang sangat parah, di samping itu juga menimbulkan ancaman terjadinya korban jiwa. Bahaya letusan gunung api dapat berpengaruh langsung (primer) maupun tidak langsung (sekunder) bagi kehidupan manusia (Citra, 2010:66). Peristiwa alam dalam bentuk apa pun akan menimbulkan dampak negatif yang merugikan manusia dan perlu segera diantisipasi agar akibat negatif yang diderita oleh masyarakat tidak berlanjut berkepanjangan (Sukandarumidi, 2010:32). Oleh karenanya, diperlukan kesiapsiagaan yang tinggi dalam mengantisipasi bencana khususnya di daerah Kecamatan Sembalun yang rentan terhadap bencana erupsi gunung api. Kesiapsiagaan

adalah serangkaian kegiatan yang dilakukan untuk mengantisipasi bencana melalui pengorganisasian serta melalui langkah yang tepat guna dan berdaya guna (UU RI No.24 Tahun 2007). Kesiapsiagaan merupakan salah satu bagian dari proses manajemen bencana dan di dalam konsep pengelolaan bencana yang berkembang saat ini. Peningkatan kesiapsiagaan merupakan salah satu elemen penting dari kegiatan pengurangan risiko bencana yang bersifat proaktif, sebelum terjadinya suatu bencana. Menurut Carter (1991 dalamLIPI-UNESCO/ISDR,2006:5), kesiapsn merupakan tindakantindakan yang memungkinkan pemerintahan, organisasi-organisasi, masyarakat, komunitas dan individu untuk mampu menanggapi suatu situasi bencana secara cepat dan tepat guna. Berdasarkan pengertian tersebut dapat diketahui bahwa kesiapsiagaan merupakan salah satu faktor kunci dalam mengurangi risiko terhadap bencana.

Masyarakat yang siapsiaga cenderung akan mampu bertindak dengan cepat dan tepat ketika terjadi bencana, sedangkan pada masyarakat yang tidak siapsiaga cenderung akan mengalami kepanikan ketika menghadapi bencana. Keadaan tersebut sangat mempengaruhi keselamatan masyarakat, sehingga dengan kesiapsiagaan yang ada pada masyarakat akan mampu mengurangi dampak buruk yang ditimbulkan jika terjadi suatu bencana.

Berdasarkan permasalahan yang telah diuraikan di atas maka dilakukan penelitian mengenai "Kesiapsiagaan Bencana Erupsi Gunung Baru Jari Pada Masyarakat di Kecamatan Sembalun Kabupaten Lombok Timur".

\section{METODE}

Penelitian ini merupakan penelitian deskriptif, dengan teknik pengambilan sampel secara "Proporsional Random Sampling", yaitu dalam penelitian ini sebanyak 
155 sampel. Pengumpulan data primer menggunakan metode koesioner dan data sekunder menggunakan pencatatan dokumen, yang selanjutnya dianalisis dengan metode deskriptif kualitatif. Analisis tersebut dibantu oleh pendekatan geografi. Pendekatan geografi yang digunakan yaitu pendekatan keruangan dan kelingkungan.

\section{HASIL DAN PEMBAHASAN}

\section{Tingkat Kesiapsiagaan \\ Bencana Erupsi Gunung Api \\ Baru Jari Pada Masyarakat di Kecamatan Sembalun}

Data terkait tingkat kesiapsiagaan bencana erupsi gunung api Baru Jari akan dianalisis dengan metode deskriptif-kualitatif dengan menggunakan pendekatan Keruangan. Penekanan dalam analisis ini adalah pada variasi gejala yang ditimbulkan.

$$
\text { Pengumpulan }
$$

data menggunakan kuesioner yang terdiri dari 20 pertanyaan yang terkait dengan tingkat kesiapsiagaan masyarakat dalam menghadapi bencana erupsi. Setiap pertanyaan memiliki skor yang berkisar 1 sampai 2 , sehingga skor terendah yang akan diperoleh adalah 20 sedangkan skor tertinggi adalah 40 . Selanjutnya akan digunakan rentangan menurut MPBI UNESCO, 2007 sebagai berikut.
a. $\quad 20-24=$ Sangat Tidak Siap
b. $>24-28=$ Tidak Siap
c. $>28-32=$ Cukup Siap
d. $>32-36=$ Siap
e. $>36-40=$ Sangat Siap

Hasil penelitian terhadap
tingkat kesiapsiagaan bencana
erupsi gunung Baru Jari pada
masyarakat di Kecamatan Sembalun, Kabupaten Lombok Timur dapat dilihat pada Tabel 0.1 berikut.
Tabel 0.1

Hasil Tingkat Kesiapsiagaan
Bencana Erupsi Gunung Baru Jari
Pada Masyarakat di Kecamatan
Sembalun

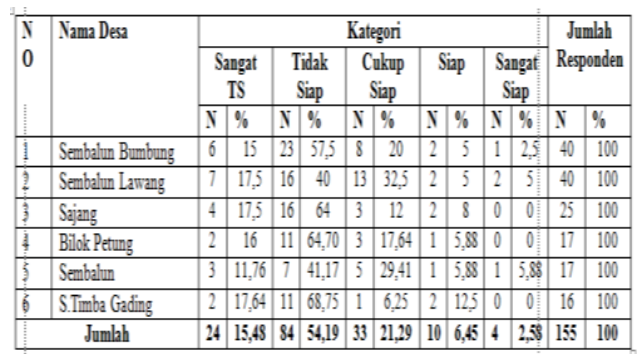

Sumber: Analisis Data Primer, 2016

Berdasarkan Tabel 0.1 dapat diketahui bahwa secara umum tingkat kesiapsiagaan Bencana Erupsi Gunung Api Baru Jari pada masyarakat di Kecamatan Sembalun tergolong tidak siap sebanyak 84 responden $(54,19 \%)$. Hal tersebut secara konsisten terlihat pada 6 desa yang ada di Kecamatan. Tingkat kesiapsiagaan masyarakat yang paling rendah terletak di Desa Sembalun Timba Gading, yaitu $12,5 \%$, sedangkan tingkat kesiapsiagaan yang paling tinggi terdapat di Desa Sembalun yaitu $17,64 \%$ dari 155 responden. Dari keenam desa yang ad di Kecamatan Sembalun terdapat empat desa yang tergolong "tidak siap", yaitu Desa Sembalun Bumbung, Desa Sajang, Desa Bilok Petung dan Desa Sembalun Timba Gading. Sedangkan kategori desa yang "cukup siap", yaitu Desa Sembalu dan Sembalun Lawang.Hasil penelitian ini sejalan dengan penelitian Taris, (2015) yang meneliti tentang pengaruh media informasi terhadap kesiapsiagaan masyarakat dalam menghadapi bencana Letusan Gunung Api di Wilayah Gunung Slamet Kabupaten Banyumas. Hasil penelitian tersebut menunjukkan bahwa sebagian besar responden terkategori tidak siap sejumlah 38 responden $(38,77)$ dari total 98 responden. Perbedaan hasil tersebut terletak pada pengambilan 
sampel. Pada penelitian Taris (2015) mengambil sampel pada empat Kecamatan yang ada di Kabupaten Banyumas yang masing-masing Kecamatan mengambil satu desa untuk dijadikan sampel penelitian. Dari empat desa tersebut jika dilakukan perhitungan, Desa Kemutug berada dalam tingkat "Siap", Desa Rempoah berada dalam tingkat "tidak Siap", Desa Kutaliman berada dalam tingkat "tidak Siap" dan Desa Kotayasa berada dalam tingkat "tidak Siap". Kedua sampel tersebut sudah samasama mengalami kejadian bencana erupsi dan secara umum tingkat kesiapsiagaan tergolong "tidak siap". Untuk lebih jelasnya mengenai tingkat kesiapsiagaan bencana erupsi Gunung Baru Jari di Kecamatan Sembalun dapat di lihat pada Gambar 0.1 di bawah ini.



Gambar $\quad 0.1 \quad$ Peta Tingkat Kesiapsiagaan Bencana Erupsi Gunung Baru Jari

Berdasakan Gambar 0.1 dapat diketahui bahwa kesiapsiagaan bencana erupsi Gunung Baru Jari pada masyarakat di Kecamatan Sembalun pada masing-masing desa memiliki kategori yang berbeda yaitu tidak siap dan cukup siap, dimana desa yang tergolong cukup siap terdapat di Desa Sembalun yaitu 28,23 dan Desa Sembalun Lawang yaitu 28,12. Sedangkan desa yang tidak siap terdapat di Desa Sembalun Bumbung sebesar 27,47, Desa Sajang sebesar 27 dan Biluk Petung sebesar 26,94 dan Desa Sembalun Timba Gading sebear 26,93. Berdasarkan skor rata-rata yang diperoleh, skor paling tinggi berada di desa Sembalun yaitu 28,23 sedangkan skor terendah berada pada desa Sembalun Timba Gading yaitu 26,93. Berdasarkan skor ratarata tersebut dapat di ketahui bahwa tingkat kesiapsiagaan bencana erupsi paling tinggi terdapat di Desa Sembalun, sedangkan tingkat kesiapsiagaan bencana erupsi paling rendah terdapat di Desa Sembalun Timba Gading. Pada Desa Sembalun Timba Gading merupakan desa yang paling dekat dengan lokasi Gunung Baru Jari, sehingga dapat terkena dampak yang paling buruk jika terjadi bencana erupsi.

Jika dilihat pada indikator yang digunakan dalam penelitian, hasil terendah adalah pada mobilitas sumber daya. Rendahnya mobilitas sumber daya manusia di daerah penelitian tidak terlepas dari kurangnya penyuluhan sosialisasi terkait dengan bencana. Menurut LIPI-UNESCO (2006), Mobilitas sumber daya yang tersedia, baik sumber daya manusia (SDM) maupun pendanaan dan saranaprasarana penting untuk keadaan darurat, mobilitas sumber daya merupakan potensi yang dapat mendukung atau sebaliknya menjadi kendala dalam kesiapsiagaan bencana terutama pada bencana erupsi. 


\section{Faktor yang Mempengaruhi Tingkat Kesiapsiagaan Bencana Erupsi pada Masyarakat di Kecamatan Sembalun}

Faktor yang mempengaruhi tingkat kesiapsiagaan bencan erupsi di Kecamatan Sembalun terdiri dari faktor pengetahuan, sistem informasi, kerentanan dan frekuensi simulasi.

Berdasarkan hasil penelitian menunjukkan bahwa sebanyak 84 responden $(54,19 \%)$ masyarakat di Kecamatan Sembalun yang tidak mengetahui tentang erupsi. Hal tersebut secara konsisten terlihat pada 6 desa yang ada di Kecamatan Sembalun yaitu Desa Sembalun Bumbung sebanyak 42,5\%, Desa Sembalun Lawang sebanyak 50\%, Desa Sajang sebanyak 52,25\%, Desa Bilok Petung sebanyak $76,47 \%$, Desa Sembalun sebanyak $52,94 \%$ dan Desa Sembalun Timba Gading sebanyak 75\%. Tingkat pengetahuan masyarakat yang paling rendah terdapat di Desa Bilok Petung dan tingkat pengetahuan masyarakat yang paling tinggi terdapat di Desa Sembalun Bumbung. Rendahnya tingkat pengetahuan masyarakat di Kecamatan Sembalun disebabkan oleh sebagian besar tingkat pendidikan/pengetahuan masyarakat tentang erupsi tergolong rendah, yaitu didominasi oleh tamatan SD $35,29 \%$, SMP $35,29 \%$ dan SMA $29,41 \%$, bahkan sangat jarang responden yang melanjutkan pendidikan hingga tingkat yang lebih tinggi yaitu diploma/serjana.

Berdasarkan hasil penelitian menunjukkan bahwa sebanyak 89 responden $(57,41 \%)$ masyarakat di Kecamatan Sembalun yang mengatakan tersedianya informasi mengenai bencana erupsi di Kecamatan Sembalun bahkan pada saat darurat. Hasil tersebut secara konsisten terlihat pada enam desa yang ada di Kecamatan Sembalun yaitu Desa Sembalun Bumbung sebanyak 24 responden (60\%), Desa Sembalun Lawang sebanyak 21 responden (52,5\%), Desa Sajang sebanyak 15 responden $(60 \%)$, Desa Bilok Petung sebanyak 8 responden (47,05\%), Desa Sembalun sebanyak 13 responden $(76,47 \%)$ dan Desa Sembalun Timba Gading sebanyak 8 responden $(50 \%)$. Sebagian besar masyarakat di Kecamatan Sembalun sudah mengetahui informasi mengenai bencana erupsi, namun terkadang informasi tersebut sering diabaikan oleh masyarakat disekitar. Hal tersebut dikarenakan kurangnya penegetahuan masyarakat terhadap bencana erupsi serta dampak yang ditimbulkan oleh erupsi.

Hasil penelitian menunjukkan
bahwa distribusi frekuensi kerentanan di Kecamatan Sembalun sebagian besar mayoritas kurang baik yaitu sebanyak 94 responden $(60,64 \%)$. Hal ini disebabkan karena masyarakat dikecamatan sembalun sebagian besar tidak tahu bahwa tempat tinggal mereka termasuk dalam jalur yang rentan terhadap bencana erupsi Gunung Baru Jari. Selain itu sebagian masyarakat membangun/mendirikan rumah tidak memperhatikan struktur bangunan dan lokasi yang aman terhadap bencana letusan gunung Baru Jari. Hal inilah yang menyebabkan salah satu faktor yang membuat rumah/bangunan cepet roboh karena tidak memperhatikan struktur bangunan serta lokasi yang rentan terhadap bencana.

Hasil penelitian menunjukkan yaitu sebanyak $59,35 \%$ masyarakat di Kecamatan Sembalun tidak mengerti tentang simulasi terhadap bencana erupsi. hal ini disebabkan karena kurangnya pengetahuan tentang simulasi penyelamatan/evakuasi dari bencana erupsi gunung Baru Jari, bahkan sebagian dari masyarakat di 
Kecamatan Sembalun juga belum pernah melakukan simulasi evakuasi terhadap bencana. Faktor lainnya juga instansi yang berwenang dalam masalah bencana juga belum sepenuhnya memberikan penyuluhan berkaitan dengan letusan gunung Baru Jari di Kecamatan Sembalun, Kabupaten Lombok Timur.

Berdasrkan permasalahan mengenai faktor yang mempengaruhi tingkat kesiapsiagaan bencana erupsi Gunung Api Baru Jari pada masyarakat di Kecamatan Sembalun, terdapat faktor yang paling dominan yang mempengaruhi tingkat kesiapsiagaan bencana erupsi adalah faktor sistem informasi sebanyak 89 responden atau $57,41 \%$, yang kemudian didominasi oleh 4 desa yang terkategori tidak siap, yaitu Desa Sembalun Bumbung, Desa Sajang, Desa Bilok Petung dan Desa Sembalun Timba Gading sedangkan kategori "cukup siap" didominasi oleh 2 desa, yaitu Desa Sembalun dan Sembalun Lawang.

\section{Kendala Masyarakat dalam Meningkatkan Kesiapsiagaan Bencana Erupsi}

Terkait dengan kendala yang dihadapi masyarakat dalam meningkatkan kesiapsiagaan bencana erupsi yaitu berkaitan dengan kendala fisik dan non fisik. Kendala fisik yaitu berkaitan dengan ketersediaan jalur evakuasi, ketersediaan sarana transfortasi dan ketersediaan sarana komunikasi. Sedangkan kendala non fisik yaitu berkaitan dengan adanya organisasi masyarakat.

1) Kendala fisik

Berdasarkan hasil penelitian menunjukkan sebanyak $51,61 \%$ masyarakat di Kecamatan Sembalun tidak menggunakan jalur evakuasi untuk evakuasi pada saat bencana erupsi terjadi. Hal tersebut secara konsisten terlihat pada enam desa, yaitu Desa Sembalun Bumbung sebanyak 21 responden (52,5\%), Desa Sembalun Lawang sebanyak 25 responden $(62,5 \%)$, Desa Sajang 15 responden (60\%), Desa Bilok Petung sebanyak 10 responden $(58,82 \%)$, Desa Sembalun sebanyak 5 responden $(29,41 \%)$, dan Desa Sembalun Timba Gading sebanyak 8 responden (50\%). Rendahnya ketersediaan Jalur evakuasi tersebut disebabkan oleh kurangnya pemahaman masyarakat di Kecamatan Sembalun tentang fungsi dari ketersediaan jalur evakuasi. Selain itu banyak diantara mereka hanya menggunakan insting untuk melakukan evakuasi terhadap bencana erupsi. Berikut adalah salah satu jalur evakuasi bencana erupsi di kecamatan Sembalun, Kabupaten Lombok Timur.

Hasil penelitian penunjukkan sebanyak 84 responden (54,19\%) masyarakat di Kecamatan Sembalaun tidak memiliki ketersediaan/kecukupan kendaraan dalam melakukan evakuasi pada saat bencan erupsi. Hasil tersebut secara konsisten terlihat pada enam desa yang ada di Kecamatan Sembalun yaitu Desa Sembalun Bumbung sebanyak 22 responden (45\%), Desa Sembalun Lawang sebanyak 22 responden (45\%), Desa Sajang 15 responden $(60 \%)$, Desa Bilok Petung sebanyak 10 responden (58,82\%), Desa Sembalun sebanyak 8 responden $(47,05 \%)$, dan Desa Sembalun Timba Gading sebanyak 7 responden (43,75\%). Ketersediaan sarana transportasi paling banyak terletak di Desa Sembalun Timba Gading dan ketersediaan sarana transportasi paling sedikit terletak di Desa Sajang. Keadaan tersebut disebabkan oleh kurangnya ketersediaan sarana transportasi saat melakukan evakuasi, sebagian besar masyarakat melakukan evakuasi dengan menggunakan 
kendaraan berpenumpang sedikit seperti kendaraan bermotor/roda dua, sedangkan kendaraan yang berpenumpang banyak seperti truk, mobil dan lainnya masih sangat terbatas. Kurangnya sarana transportasi dapat memperlambat proses evakuasi pada saat bencana erupsi terjadi dan dapat mempengaruhi rendahnya tingkat kesiapsiagaan terhadap bencana erupsi pada daerah yang rentan terhadap bencana.

Hasil penelitian menunjukkan sebanyak 89 responden $(57,41 \%)$ masyarakat di Kecamatan Sembalun yang mengetahui informasi, baik informasi mengenai proses bencana erupsi sampai dengan proses evakuasi berlangsung. Hasil tersebut secara konsisten terlihat pada enam desa yang ada di Kecamatan Sembalun yaitu Desa Sembalun Bumbung sebanyak 23 responden (57,5\%), Desa Sembalun Lawang sebanyak 21 responden (52,5\%), Desa Sajang 14 responden (56\%), Desa Bilok Petung sebanyak 10 responden (58,82\%), Desa Sembalun sebanyak 12 responden (70,59\%), dan Desa Sembalun Timba Gading sebanyak 9 responden (56,25\%). Ketersediaan sarana komunikasi mengenai bencana erupsi di Kecamatan Sembalun tergolong cukup baik dan rata-rata mencapai $50 \%$ ke atas, bahkan pemerintah juga telah memberikan sumbangan berupa Handy Talky (HT) untuk menyalurkan informasi mengenai bencana. Namun terkadang informasi tersebut sering diabaikan oleh masyarakat disekitar. Hal tersebut dikarenakan kurangnya pengetahuan masyarakat tentang bencana erupsi dan dampak yang ditimbulkan oleh erupsi.

2) kendala non fisik

Selain kendala fisik terdapat juga kendala non fisik yang dihadapi masyarakat dalam meningkatkan kesiapsiagaan terhadap bencana erupsi gunung Baru Jari di Kecamatan Sembalun, Lombok Timur. Kendala non fisik tersebut berkaitan dengan organisasi masyarakat. Organisasi kemasyarakatan yang dimaksud dalam hal ini adalah adanya kegiatan gotong royong. Gotong royong merupakan salah satu bentuk implementasi sosial, sehingga indikator dalam organisasi kemasyarakatan dapat menunjukkan kebersamaan dalam masyarakat. Hasil penelitian menunjukkan sebanyak 135 responden (87,09\%) masyarakat di Kecamatan Sembalun masih melakukan gotong royong setelah terjadinya erupsi (Tabel 4.17). Hasil tersebut secara konsisten terlihat di enam desa yaitu Desa Sembalun Bumbung sebanyak 35 responden ii(87,5\%), Desa Sembalun Lawang sebanyak 37 responden $(92,5 \%)$, Desa Sajang 23 responden (92\%), Desa Bilok Petung sebanyak 13 responden (76,47\%), Desa Sembalun sebanyak 14 responden $(82,35 \%)$, dan Desa Sembalun Timba Gading sebanyak 13 responden (81,25\%), namun sisanya sebanyak $12,90 \%$ masyarakat tidak melakukan kegiatan gotong royong setelah terjadinya erupsi di wilayah Kecamatan Sembalun, dikarenakan adanya relokasi tempat tinggal hunian sementara.

telah $\begin{gathered}\text { Berdasarakan uraian yang } \\ \text { dipaparkan dalam }\end{gathered}$ pembahasan mengenai kendala yang dihadapi masyarakat dalam meningkatkan kesiapsiagaan terhadap bencana erupsi gunung Baru Jari di Kecamatan Sembalun. Terdapat kendala yang paling dominan yang dihadapi masyarakat dalam meningkatkan kesiapsiagaan bencana erupsi, yaitu kendala ketersediaan sarana trasportasi sebanyak 84 responden (54,19\%) masyarakat di kecamatan sembalun yang masih kekurangan/tidak 
tersedianya sarana transportasi pada saat bencana erupsi. Hal ini disebabkan oleh kurangnya ketersediaan sarana transportasi saat melakukan evakuasi, sebagian besar masyarakat melakukan evakuasi dengan menggunakan kendaraan berpenumpang sedikit seperti kendaraan bermotor/roda dua, sedangkan jumlah penduduk di Kecamatan Sembalun tergolong banyak, sehingga jika menggunakan kendaraan roda dua akan mempersulit proses evakuasi. Kemudian jumlah kendaraan yang berpenumpang banyak seperti truk, mobil dan lainnya masih sangat terbatas. Kurangnya sarana transportasi dapat memperlambat proses evakuasi. Oleh sebab itu, perlunya antisipasi sejak awal agar ketika terjadi bencana erupsi, proses evakuasi yang dilakukan dapat dilakukan secara cepat sehingga mengurangi tingkat risiko bencana.

\section{SIMPULAN DAN SARAN}

Berdasarkan hasil dan pembahasan yang telah diuraikan mengenai kesiapsiagaan bencana erupsi Gunung Baru Jari pada masyarakat di Kecamatan Sembalun Kabupaten Lombok Timur, maka diperoleh simpulan yaitu sebagai berikut. (1) Tingkat kesiapsiagaan bencana erupsi Gunung Baru Jari pada masyarakat di Kecamatan Sembalun secara umum terkategori "tidak siap", yaitu sebanyak 54,19\%. Hal tersebut secara konsisten terlihat pada 6 desa yang ada di Kecamatan Sembalun. Desa yang tergolong tidak siap mencakup Desa Sembalun Bumbung sebanyak 27,47\%, Desa Sajang 27\%, Desa Bilok Petung 26,94\%, dan Desa Sembalun Timba Gading 26,93\%. Sedangkan desa yang tergolong "Cukup Siap" mencakup Desa Sembalun,yaitu 28,23\% dan Desa Sembalun Lawang, yaitu $28,12 \%$, (2)Faktor-faktor yang mempengaruhi tingkat kesiapsiagaan bencana erupsi Gunung Baru Jari pada masyarakat di Kecamatan Sembalun terdiri dari faktor pengetahuan, sistem informasi, kerentanan dan frekuensi simulasi. Faktor yang paling dominan yang berpengaruh terhadap tingkat kesiapsiagaan bencana erupsi Gunung Api yaitu faktor Sistem Informasi sebanyak $59,41 \%$, dan (3) Kendala yang dihadapi masyarakat dalam meningkatkan kesiapsiagaan bencana erupsi Gunung Api Baru Jari, yaitu kendala fisik meliputi ketersediaan jalur evakuasi, ketersediaan sarana transportasi, dan ketersediaan sarana komunikasi. Sedangkan kendala non fisik meliputi organisasi masyarakat. Kendala yang sangat dominan yang dihadapi masyarakat dalam meningkatkan kesiapsiagaan bencana erupsi Gunung Baru Jari di Kecamatan Sembalun yaitu ketersediaan sarana transportasi. Kurangnya ketersediaan sarana transportai pada saat bencana erupsi dapat mempengaruhi tingkat kesiapsiagaan di Kecamatan Sembalun, Lombok Timur.

\section{UCAPAN TERIMAKASIH}

Penelitian ini dapat diselesaikan berkat bimbingan dari berbagai pihak. Untuk ini pada kesempatan ini diucapkan terima kasih yang setulus-tulusnya kepada Rektor Universitas Pendidikan Ganesha, Dekan Fakultas Hukum dan Ilmu Sosial, Ketua Program Studi Pendidikan Geografi, staff dosen di Program Studi Pendidikan Geografi, Pembimbing Akademik, Pembimbing 1, Pembimbing 2, Penguji 1, dan Penguji 2, Dinasdinas pemerintahan di Kab. Lombok Timur, Bapak Camat Sembalun, Bapak Kepala Desa Sembalun Bumbung, Bapak Kepala Desa Sembalun Lawang, Bapak Kepala Desa Sembalun, Keluarga tercinta, situs internet penyedia data (BMKG dan BPS) dan rekan-rekan 
mahasiswa Program Studi

Pendidikan Geografi angkatan 2012.

\section{DAFTAR PUSTAKA}

Bakornas PB. 2007. Pengenalan Karakteristik Bencana dan Upaya Mitigasinya di Indonesia. Jakarta: Lakhar Bakornas PB.

BPS Kabupaten Lombok Timur. Kecamatan Sembalun Dalam Angka 2016.

Citra, Putu Ananda. 2010. Perubahan Kondisi Sosial Ekonomi Masyrakat Desa Glaharjo Pada Erupsi Gunung Api Merapi. Media Komunikasi Geografi, FIS Universitas Pendidikan Ganesha, Singaraja. Vol. 13, No 1 (hlm. 65-77).

Kardinasari, Noneng Nita. 2014. Tingkat Kerentanan Bencana Letusan Gunung Api galunggung di Kabupaten Tasikmalaya. Universitas Pendidikan Indonesia: repository.upi.edu.

LIPI-UNESCO/ISDR. 2006. Kajian Kesiapsiagaan Masyarakat dalam Mengantisipasi Bencana Gempa Bumi dan Tsunami. Jakarta: Lembaga IImu Pengetahuan Indonesia.

Sukandarumidi. 2010. Bencana Alam dan Bencana Anthropogene. Yogyakarta: Kanisius

Undang-Undang No. 24 Tahun 2007 tentang Penanggulangan Bencana
Taris, Encep Cahyadi. 2015. "Pengaruh Media Informasi Terhadap Kesiapsiagaan

Masyarakat dalam Menghadapi Bencana Letusan Gunung Slamet Kabupaten Banyumas". Skripsi. Jurusan Pendidikan Geografi, Universitas Pendidikan Indonesia

Wesnawa, I Gede Astra dan Putu Indra Christiawan. 2014. Geografi Bencana. Yogyakarta: Graha IImu. 